\title{
Training in Neurology: Resident Perception of the Utility and Applicability of Global Neurology Morning Reports
}

Andrew M. Agostini, MD, Michael R. Halstead, MD, MPH, Arun Venkatesan, MD, PhD, and Deanna R. Saylor, MD, MHS

Neurology ${ }^{\circledR}$ 2022;98:44-47. doi:10.1212/WNL.0000000000012950
Correspondence

Dr. Saylor

deanna@jhmi.edu

\begin{abstract}
Interest in global health is increasing among neurology residents. However, funding, time, and, recently, COVID-19 travel restrictions remain barriers to widespread participation. To meet this need, we instituted virtual global neurology morning reports with the objectives of (1) improving knowledge about neurologic diseases common in sub-Saharan Africa and (2) developing clinical reasoning skills through consideration of diagnostic and therapeutic limitations in resource-limited settings. Interactive case-based sessions were presented from Zambia via videoconference by a Johns Hopkins faculty member or Zambian neurology trainee. An anonymous cross-sectional survey was conducted among Johns Hopkins neurology residents. Of eligible participants, $69 \%(n=30)$ completed the survey, $66 \%$ of whom were female, and $33 \%$ reported prior in-person global health experience. Although most participants did not anticipate a career in global health, the majority $(85 \%)$ reported that exposure to global health was important. All but 1 participant (96\%) reported satisfaction with the global neurology morning reports, with $100 \%$ reporting that they were useful to their clinical knowledge and $86 \%$ reporting that they were useful to their clinical practice. All respondents felt that morning reports should continue, and $69 \%$ ranked the educational value of the experience in the top quartile of the residency curriculum. Resident satisfaction with and perceived utility of global neurology morning reports were high, although the majority did not plan to pursue global neurology opportunities as part of their career. Remote learning opportunities may increase interest in global health among neurology residents.
\end{abstract}

From the Department of Neurology (A.M.A., A.V., D.R.S.), Johns Hopkins University School of Medicine, Baltimore, MD; Sentara Pulmonary (M.R.H.), Critical Care and Sleep Specialists, Norfolk, VA; and Department of Medicine (D.R.S.), University Teaching Hospital, Lusaka, Zambia.

Go to Neurology.org/N for full disclosures. Funding information and disclosures deemed relevant by the authors, if any, are provided at the end of the article. 
Interest in global health has increased among undergraduate students, medical students, and residents, ${ }^{1-3}$ including neurology residents, ${ }^{4}$ likely reflecting the growing burden of neurologic disease in low- and middle-income countries. 5,6 However, formalized global neurology training tracks ${ }^{7}$ and curricula are rare, ${ }^{8}$ with only one-half of US and Canadian neurology programs offering global health electives, ${ }^{4}$ thus potentially limiting resident training and exposure to the field.

Approaches to educating US trainees in global health have primarily focused on opportunities for in-person international electives, which are resource and time intensive. Costs, logistics, elective time, and, more recently, COVID-19associated travel restrictions are all major barriers to participation, even among highly motivated trainees. ${ }^{7-10}$ With $<10 \%$ of neurology trainees participating, ${ }^{4}$ only trainees with the greatest preexisting interest and exposure to global health are likely to benefit from such exchanges. Other global neurology training opportunities are vastly limited for trainees unwilling or unable to complete in-person electives. Thus, most US neurology residents have little exposure to neurologic disorders more commonly seen in resource-limited settings, but which may be encountered in travelers and immigrants. Furthermore, most trainees may never gain exposure to this potential career pathway.

The Johns Hopkins neurology residency program expanded its traditional global health offerings to include a novel virtual approach with the objectives of (1) improving knowledge of neurologic diseases common in sub-Saharan Africa and (2) developing clinical reasoning skills through consideration of diagnostic and therapeutic limitations in resource-limited settings. In this study, we define trainees' perceptions and interest in global neurology and assess the format, content, and educational value of the global neurology morning report series.

\section{Program Description}

After establishing an international collaboration in Zambia, a bimonthly interactive case-based videoconference series was implemented in March of 2018 during scheduled morning report times as part of the core residency educational curriculum. Cases are presented from Zambia via Skype or Zoom on the first and third Mondays of the month during regularly scheduled morning report times for the Johns Hopkins neurology residency program (7:30 AM-8:00 AM Eastern Standard Time/1:30 PM-2:00 PM Central African Time). The content represents the broad range of conditions encountered in a large teaching hospital in an urban setting in Zambia and includes neuroinfectious diseases, neuroinflammatory diseases, neuro-oncologic disease, and neurologic manifestations of toxic and metabolic disorders.

Cases are often presented by a Johns Hopkins faculty neurologist based in Zambia (D.R.S.) but are also presented by
Zambian neurology trainees. Each session begins with an interactive case presentation. Resident volunteers then discuss possible localizations, differential diagnoses, and further diagnostic and management plans taking into account local resource limitations. Following the case, approximately 10 minutes is devoted to a didactic on the topic of the case. Neurology residents from both Johns Hopkins and Zambia attend the morning reports. Between March 2018 and June 2020, 35 sessions were held.

\section{Assessment}

\section{Survey}

An electronic survey using Qualtrics was distributed via email in July 2020 to all current adult and pediatric neurology residents in their second or third year of neurology training at the Johns Hopkins Hospital. 2019 and 2020 graduates from the program were also included $(n=43)$. Current first-year neurology residents were excluded as the survey was distributed during the first 2 weeks of their neurology training. Participation was voluntary and confidential. The survey included 18 multiple choice, Likert scale, and open-ended questions regarding participant demographics, prior global health experiences, interest in global health, and perceptions of global neurology. Trainee interest, value, and feedback on the global neurology morning reports were also assessed. Participants had 1 month to complete the survey. Two reminders were sent via email every 2 weeks before survey closure.

\section{Ethics}

The study was approved by the Johns Hopkins University Institutional Review Board.

\section{Statistical Analysis}

Descriptive characteristics are presented for the cohort and stratified by participant characteristics. Group differences were assessed using Fisher exact tests or analysis of variance. Analyses were performed using RStudio and Microsoft Excel.

\section{Outcomes}

Survey respondents ( $n=30$ of $43,69 \%)$ were $66 \%$ female $(n=$ $20)$, and $53 \%(\mathrm{n}=16)$ were recent graduates (eTable 1, links. lww.com/WNL/B614). One-third reported prior global health experiences, primarily occurring during medical school (39\%) or residency $(22 \%)$.

Participants with prior global neurology exposure $(n=10)$ uniformly planned to pursue global health in their future, whereas only $21 \%$ of participants $(n=4)$ without prior global neurology experience reported interest in global neurology careers $(p<0.001)$. Still, most participants $(85 \% ; \mathrm{n}=24)$ reported that gaining exposure to global health was either very or somewhat important. There was no significant difference in response by year of training or prior global health experiences. 

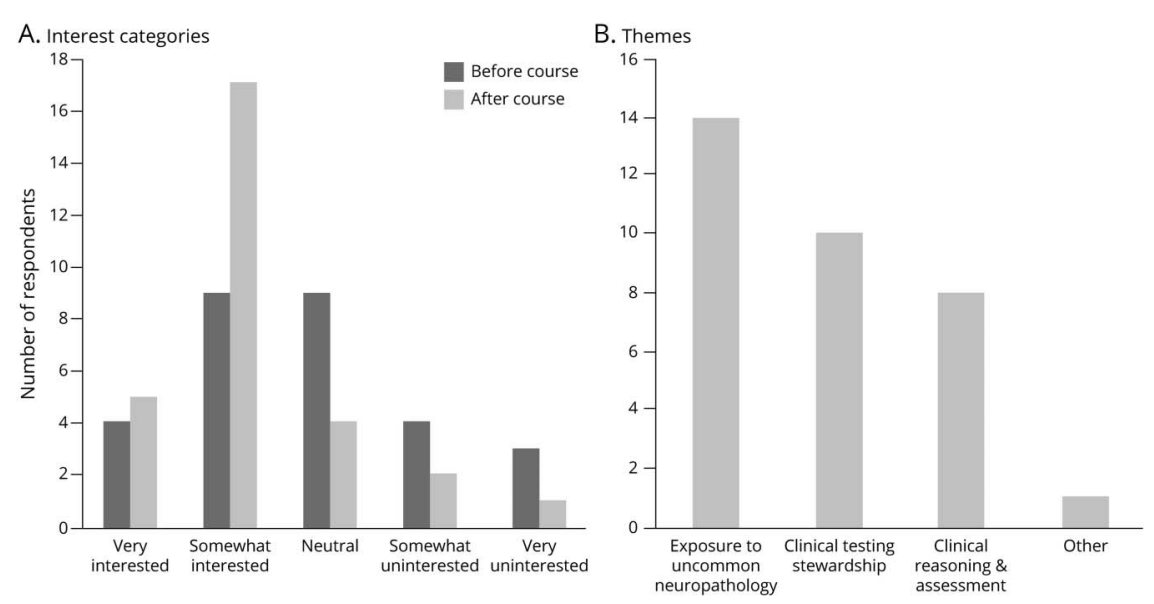

(A) Self-reported interest in global neurology
before and after exposure to global neurology
morning reports. (B) Self-reported responses
regarding the most useful part of global neurol-
ogy morning reports.

Cited benefits of global health exposure included better understanding of the pathophysiology, diagnosis, and treatment of neurologic diseases less commonly encountered in the United States (93\%); improved ability to think critically about the necessity of diagnostic tests ordered (93\%); and greater preparation to care for patients in the United States with limited access to health care (89\%) and international and immigrant patients in the United States (86\%) (eTable 2, links.lww.com/WNL/B614).

Most participants attended at least 3-5 global neurology morning reports over an academic year and at least 6-10 during their residency training. Nearly all (96\%) participants reported satisfaction with the series, with $72 \%$ reporting that they were very satisfied. All participants found the information useful to their clinical knowledge, whereas $86 \%$ found the information relevant to their clinical practice. All respondents believed the series should continue. When asked to rank the educational value of the global neurology curriculum in comparison to other educational opportunities in the neurology program, 69\% ranked it in the top quartile of the overall curriculum.

Although only $45 \%$ of participants reported global neurology interest before the curriculum, $76 \%$ reported interest after the curriculum ( $p=0.19$, Figure, A). Respondents highlighted exposure to uncommon neuropathology and clinical testing stewardship among the most useful aspects of the curriculum (Figure, B), whereas technical issues and changes to lecture content were the most frequently suggested changes (Table).

\section{Lessons Learned}

Although most residents did not plan global neurology careers, the majority reported that exposure to global health was important for learning about neurologic diseases uncommon in the United States, enhanced clinical reasoning, medical test stewardship, and preparation for caring for underserved patients. Overall resident satisfaction and perceived utility of global neurology morning reports were high, with a majority ranking the curriculum in the top quartile of the overall residency curriculum. Interest in global health increased among residents exposed to the curriculum. Suggestions for improvement included expansion of lecture content and improvement in technical issues.

Study limitations include the response rate (69\%), which is typical for self-reported surveys, but may limit generalizability of the results. Including residents who had recently graduated may have introduced recall bias. Residents with a strong interest in global health may have been more likely to participate making responses more favorable than what would be found among the overall group. Also of note, less than half of

Table Free-Text Responses Regarding Suggested Changes to the Global Neurology Morning Reports

\begin{tabular}{lll}
\hline Theme & $\mathbf{n}(\%)$ & Illustrative quotes \\
\hline $\begin{array}{ll}\text { Lecture } \\
\text { content }\end{array}$ & $8(40 \%)$ & "Have more [lectures]" \\
& & "More pediatric cases" \\
\cline { 3 - 3 } & & "See and interact with the patient [presented]" \\
\cline { 3 - 3 } & & "Add speakers who work in underserved areas" \\
\cline { 3 - 3 } & & "Metween countries" \\
Technical & $5(25 \%)$ & "Reliability of network connection" \\
\cline { 3 - 3 } & & "Connection issues can make it difficult" \\
\hline No change & $6(30 \%)$ & "Nothing, they are excellent" \\
\hline
\end{tabular}

Responses were grouped into common themes. The percentages listed represent the number of respondents whose free-text response was included that theme. However, participants' responses could correspond to multiple themes, so the total percentage is greater than $100 \%$. 
neurology residents generally attend each morning report due to a combination of night float rotations, call schedules, offsite and elective rotations, and other scheduling limitations, but attendance at global neurology morning reports does not differ significantly from other morning report formats.

Our program highlights that remote learning opportunities can provide global neurology exposure for residents who may face common barriers to in-person experiences such as limited institutional opportunities, financial support, or elective time. $^{7-9}$ Furthermore, our program provides global health exposure from the start of neurology training, thus overcoming the limitations of delayed exposure, which is less likely to result in a sustained commitment to global health. ${ }^{10}$

Finally, this program primarily focuses on educational benefits to the Johns Hopkins neurology residents as a novel addition to their formal residency program educational curriculum. Although the Zambian neurology residents also benefit from the series, having Zambian neurology residents attend morning reports in which Hopkins neurology residents present cases would increase the bidirectionality of this exchange. Although this design was discussed, the Zambian program had already developed similar partnerships with other US academic institutions and thus felt that it would not add additional benefit to their curriculum.

\section{Future Directions}

Remote learning may improve global neurology exposure among residents while overcoming common barriers to in-person experiences. Longer-term studies are needed to investigate the impact of such programs, including whether trainees exposed to these curricula pursue in-person global health experiences, whether knowledge gained is retained long term, and whether neurologists report improved comfort in diagnosing and managing these conditions in their future practice. Importantly, the educational impact and benefits of these global exchanges on non-US neurology trainees must also be carefully evaluated.

Finally, this virtual and interactive global health education model may be used as a framework for other medical specialties and at other institutions where there is a demand for more global health exposure among trainees. Moreover, in the era of virtual platforms, access to able instructors of global health in other countries has been made easier, and international case discussions also offer the opportunity for bidirectional education, which can augment the traditional educational format. This is of particular importance during the COVID-19 pandemic and its resultant travel restrictions, which has greatly limited exposure to global health for interested residents.

\section{Study Funding}

No targeted funding reported.

\section{Disclosure}

The authors report no disclosures relevant to the manuscript. Go to Neurology.org/N for full disclosures.

Appendix Authors

\begin{tabular}{lll}
\hline Name & Location & Contribution \\
\hline $\begin{array}{l}\text { Andrew M. } \\
\text { Agostini, MD }\end{array}$ & $\begin{array}{l}\text { Johns Hopkins University } \\
\text { School of Medicine, } \\
\text { Baltimore, MD }\end{array}$ & $\begin{array}{l}\text { Major role in the acquisition of } \\
\text { data; analyzed the data; and } \\
\text { drafted the manuscript for } \\
\text { intellectual content }\end{array}$ \\
\hline $\begin{array}{l}\text { Michael R. } \\
\text { Halstead, } \\
\text { MD, MPH }\end{array}$ & $\begin{array}{l}\text { Sentara Pulmonary, } \\
\text { Critical Care and Sleep }\end{array}$ & $\begin{array}{l}\text { Revised the manuscript for } \\
\text { intellectual content }\end{array}$ \\
\hline $\begin{array}{l}\text { Arun } \\
\text { Venkatesan, } \\
\text { MD, PhD }\end{array}$ & $\begin{array}{l}\text { Johns Hopkins University } \\
\text { School of Medicine, }\end{array}$ & $\begin{array}{l}\text { Revised the manuscript for } \\
\text { intellectual content }\end{array}$ \\
$\begin{array}{l}\text { Beannare, MD } \\
\text { Saylor, MD, } \\
\text { MHS }\end{array}$ & $\begin{array}{l}\text { Johns Hopkins University } \\
\text { School of Medicine, }\end{array}$ & $\begin{array}{l}\text { Designed and conceptualized } \\
\text { the study; analyzed the data; } \\
\text { and revised the manuscript } \\
\text { for intellectual content }\end{array}$ \\
\hline
\end{tabular}

\section{References}

1. Coupet S, Del Valle J. A case for an international health elective training program during residency: a four-points call for action. Teach Learn Med. 2013;25(3):266-271.

2. Matthews NR, Davies B, Ward H. Global health education in UK medical schools: a review of undergraduate university curricula. BMJ Global Health. 2020;5(12): e002801.

3. Mateen FJ. Neurology and international organizations. Neurology. 2013;81(4): 392-394.

4. Lyons JL, Coleman ME, Engstrom JW, Mateen FJ. International electives in neurology training: a survey of US and Canadian program directors. Neurology. 2014; 82(2):119-125.

5. Chin JH, Vora N. The global burden of neurological diseases. Neurology. 2014;83(4): 349-351.

6. GBD 2013 Mortality and Causes of Death Collaborators. Global, regional, and national age-sex specific all-cause and cause-specific mortality for 240 causes of death, 1990-2013: a systematic analysis for the global burden of disease study 2013. Lancet. 2015;385(9963):117-171.

7. Berkowitz AL, Milligan TA, Cho TA. Development of a track in global and humanitarian health for neurology residents. Neurology. 2015;85(21):1894-1895.

8. Deb A, Fischer M, Hohler AD. Education research: a framework for global health curricula for neurology trainees. Neurology. 2018;91(11):528-532.

9. Siddiqi OK, Brown M, Cooper C, Atadzhanov M, Lakhi S, Koralnik IJ. Developing a successful global neurology program. Ann Neurol. 2017;81(2):167-170.

10. Wheat S, Mendez R, Musselman R, et al. Beyond the Homestay Model: peer mentorship and early exposure in global health education. Med Sci Educ. 2016;26(3): 409-415. 


\section{Neurology}

\section{Training in Neurology: Resident Perception of the Utility and Applicability of Global Neurology Morning Reports}

Andrew M. Agostini, Michael R. Halstead, Arun Venkatesan, et al. Neurology 2022;98;44-47 Published Online before print October 13, 2021

DOI 10.1212/WNL.0000000000012950

\section{This information is current as of October 13, 2021}

\section{Updated Information \& Services}

References

Citations

Subspecialty Collections

Permissions \& Licensing

Reprints including high resolution figures, can be found at: http://n.neurology.org/content/98/1/44.full

This article cites 10 articles, 6 of which you can access for free at: http://n.neurology.org/content/98/1/44.full\#ref-list-1

This article has been cited by 1 HighWire-hosted articles: http://n.neurology.org/content/98/1/44.full\#\#otherarticles

This article, along with others on similar topics, appears in the following collection(s):

All global neurology

http://n.neurology.org/cgi/collection/all_global_neurology

Methods of education

http://n.neurology.org/cgi/collection/methods_of_education

Training-international

http://n.neurology.org/cgi/collection/training_international

Information about reproducing this article in parts (figures,tables) or in its entirety can be found online at:

http://www.neurology.org/about/about_the_journal\#permissions

Information about ordering reprints can be found online:

http://n.neurology.org/subscribers/advertise

Neurology ${ }^{\circledR}$ is the official journal of the American Academy of Neurology. Published continuously since 1951, it is now a weekly with 48 issues per year. Copyright @ 2021 American Academy of Neurology. All rights reserved. Print ISSN: 0028-3878. Online ISSN: 1526-632X.

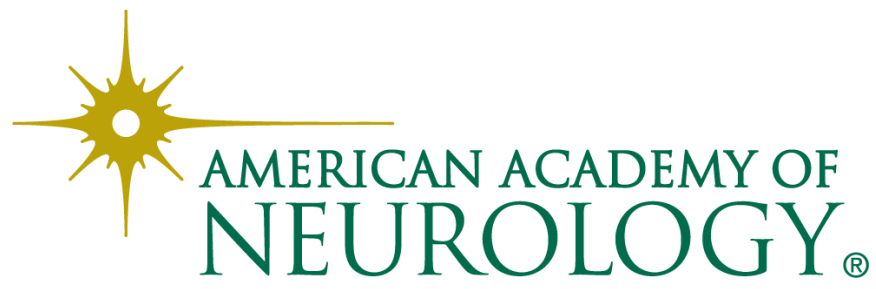

